\title{
LIBRARY RESOURCES AND FUNCTIONAL EFFECTIVENESS OF AN ACADEMIC LIBRARY: MEETING THE CHALLENGES OF THE DIGITAL AGE
}

\author{
Demetria A. Corpuz \\ Associate Professor V, College of Teacher Education, Nueva Vizcaya State University, Nueva Vizcaya, Philippines. \\ Email: demetria_corpuz@yahoo.com
}

Article History: Received on $23^{\text {rd }}$ April 2020, Revised on $28^{\text {th }}$ June 2020, Published on $17^{\text {th }}$ July 2020

\begin{abstract}
Purpose of the study: The study evaluated the strengths and weaknesses of a library system in a state-owned university to ensure that the information needs and services of clients are adequate. It looked into the available resources and required facilities to assess changes and improvement. Likewise, the functional effectiveness of the academic library was also determined.
\end{abstract}

Methodology: The study used a descriptive survey method to describe available library resources and the extent of the functional effectiveness of academic library services of the Nueva Vizcaya State University (NVSU) Philippines. The 175 respondents came from the most frequent library users. This study utilized the purposive sampling technique. Descriptive statistics were used to determine the adequacy and functional effectiveness of the library.

Result: The result revealed that the library services surpassed the minimum requirements on holdings and Filipiniana collection, but did not meet the required library collection published within the last five years. Periodicals needed to increase subscriptions and ICT required improvement. Librarians are qualified to manage the library. The respondents perceived the functional effectiveness of library services to be useful and very effective.

Novelty/Originality of this study: This research study gives an empirical data as bases on the provision of Sustainable Development Plan to cater to the nature of users in the digital age with the consideration to balance the physical and virtual resources.

Practical implications: This paper will be most helpful to academic libraries to continually revisit the resources and services to be responsive to the vision and vision of the university, demand for curriculum change, and research endeavour.

Keywords: Academic Library, Adequacy of collection, Library Resources, Library Services, Functional Effectiveness.

\section{INTRODUCTION}

A library is an indispensable unit in an academic community which is considered as the "heart of educational institution". It is a learning resource centre that houses related library materials in any form. The library is an avenue for bibliographic information searching, research endeavour, and other intellectual pursuits. Therefore, updated information and facilities that would meet the growing demands of the library users must be available (Kim, 2017). Although there is the availability of extensive information in digital references, the library is still the most desired place for users (Sun \&Yuan 2012; Kim, 2017). The advent of technology brought the emergence of change and transition in academic facilities and services (Kim 2017). This digital era posts many challenges in various fields, including academic libraries (Doherty, 2014; (Hapha \&Somprach, 2019). The librarians must be open to embrace the different modalities of services, both physical and virtual and accommodate the changing behaviour of library users (Dahan, Taib, Zainudin \& Ismail, 2016). Knowledge management is vital for academic librarians to better achieve their objectives (Reddy, 2017).

One of the primary functions of libraries is to stimulate the reading habits of the public, especially those in the academe (Bassey, 2006). Every tertiary library aims to meet the objectives of the institution (Aina, 2004). Several types of research have referred to uphold the university's vision and mission to provide quality information to library users and ensure the optimum utilization. Some studies supported that Libraries must go through a proper evaluation to reappraise their service delivery (Obille 2007; Kadiri 2000; Brophy 2006; Hernon 2010). Moreover, accreditation may be an exhausting challenge for academic libraries being one of the foci of evaluation. Certainly, it would bring out better results and enhance the quality of services and collection. Higher education needs feedback for evaluating the performance index as needed (Hapha \& Somprach, 2019). As with any assessment, the use of the results should inform the application and Implementation of new or refined library services. Academic libraries should build a culture of evaluation (Murray, 2016; Abdallah \& Bilal, 2015).

The academic library of Nueva Vizcaya State University, Philippines, is a state-run institution that supports curricular programs. It caters to the needs of the students and researchers in the province and the whole region as well. Through its different services, users have better opportunities to do their assignments, reports, research works, projects, and other academic pursuits. However, does the library have enough library resources to cater to the needs and demands of its users? How useful are their functions in terms of holdings, facilities, services, and personnel? These are the questions that motivated the researcher to conduct this study. 


\section{Objectives of the Study}

- To determine the available library resources in terms of holdings, facilities, and library personnel.

- To determine the level of functional effectiveness of holdings, facilities, services, and library personnel as assessed by the students.

- To develop a sustainable development plan for an academic library.

\section{LITERATURE REVIEW}

Several researches focus on library resources management, enhanced services, and satisfaction level of library services. The study of Dahan, Taib, Zainudin \& Ismail (2016) showed that the library users of UMP accessed and availed of the services. The findings revealed that the UMP was satisfied with the services afforded to them. According to Kim( 2017), the library is a preferred place to study and spent time during non-class times The access to information and computer resources and research support services is the essential library services offered (Besiki \& Gibradze, 2017). Further, the ultimate test of library effectiveness is the satisfaction of library clientele and the maximum utilization of resources and facilities (Gako \& Laspinas, 2015).

The study also examines literature reviews on staffing in library services and also the competence of librarians and information professionals attending to the academic community. It also evolved in library practices to have a quality workforce (Gulati 2010; Jantz 2012; Kanduik 2014; Roberts and Nobel 2016; Jaeger and Franklin 2017). It is essential to study societal, institutional, and curriculum changes because it affects services to clientele with diverse needs (Gibson et al. 2017; Agosto, Paone and Ipock, 2007).

Collection development is a continuous updating process. Library acquisition has become a challenging process amidst difficulties. The bridging from traditional library materials towards digital platforms is an evitable process (Mustafa \& Noorhidawati, (2020). Hence, it calls for a change. The study of Mustafa \& Noorhidawati (2020) showed that respondents needs' include the improvement of facilities and information technologies and extend library hours. These affect the dissatisfaction of library users. Several studies were surveyed to support the study on hand. Al Hjjii \& Coz (2012) conducted qualitative interviews with librarians on how they measure the quality of services and staff performance. It emerged that evaluation was conducted by external bodies using surveys, reports, key performance indicators, statistics, and interviews. While Oakleaf (2010) cited insights on the priorities and strategies in evaluating academic libraries; and Matthews (2014) focused on the best practices of research and academic libraries. Library users are "customers" (Taylor 1986); priority on the customers' needs (Hernon \& McClure, 1990), customers are the best judge of quality service (Kiran 2010; Taylor 1986; Whiteball 1992) customer satisfaction are bases of quality service.

Other studies also focused on space as a factor to encourage students to go to the library. The results were consistent with previous studies which are affirmed by this paper that users' study space satisfy users learning style and study preferences. It is a place frequently used and often used as a place for individual and group study (Freeman, 2005; King, Buss, Cohen, Stanley and White, 2008; Lawson 2004).

Moreover, Reddy (2017) explored the management sharing practices and determined how effective methods are, identifying strengths and weaknesses, and raised the awareness of the vital knowledge sharing practices to further information service to all clients. As a result, the role of academic libraries dynamically changes to provide benefits to the university and its clients. Instructional libraries provide assistance for instruction, research, and other educational pursuits. Libraries can use knowledge management to enhance the library's position in the management of services. Hapha \& Somprach (2019) conducted the components of Digital Leadership and Creative Leadership which affect innovation in Thai higher education. The result showed that there was a positive correlation between digital leadership and innovation and needed to be paid attention to by all elements of higher education. It became a challenge to higher education to integrate digital leadership in the curriculum.

Furthermore, researchers have conducted studies on library knowledge management. Some of the results include practitioners' awareness of knowledge management, appreciative of the benefits gained from library performance, and also for future career options; however, basic fundamental knowledge still wants (Fassoulis \& Fassoulis, 2017). Librarians also showed much concerned with 3D printing, removing bookshelves to add study space. The extended library hours and natural lighting need further attention. The lack of clarity on fundamental knowledge management is still an issue (Young \& Kelly, 2018). Additionally, Manafu (2016) conducted the readiness of the Makerere University Library to implement a KMS. The concept of knowledge management is evident among library staff but still need further training for broader understanding; technological infrastructure needs to be updated. The birth of technologies requires digital libraries for improved service (Sun \&Yuan, 2012). The study of Bamidele (2012) provides support to prior studies on building technological infrastructure.

There were earlier studies surveyed that argued for the provision of extension holdings in various forms (Echezona and Edoka, 2009). However, with the present technology, libraries are in the best position to provide numerous services. Umunnakwe and Onyebinama (2007) also proved that users are satisfied with resources and services offered but identified inadequate ICT facilities and non-operational of the virtual library as inhibitors to the utilization of 
information resources and services. In the study of Francisco (2008), e-books were ranked low compared to internet resources and print materials. There was less attention on library hours and natural lighting.

Over the years, there are researches conducted on the functionality and assessment of library resources. Still, results had minimally backed libraries on the quality level that users are looking for nor helped them determine the kinds of resources and services needed; hence, this study.

\section{METHODOLOGY}

The study used a descriptive survey method to describe available library resources and the extent of the functional effectiveness of academic library services of the Nueva Vizcaya State University (NVSU) Philippines. Purposive sampling technique was used to identify the frequent library users as respondents. A frequent user must have utilized the library for a minimum of three times a week. A total of one hundred seventy-eight questionnaires were retrieved from the respondents. The data were coded, tallied and interpreted using descriptive statistics. Document scanning on available records on file was used to determine the available resources of the library in terms of holdings, facilities, and personnel within the last five years. The survey questionnaire was validated by the research experts with a computed mean score of 4.0123. The researcher observed research ethics and protocols during the conduct of the study.

\section{RESULTS AND DISCUSSION}

\section{Available library resources in terms of holdings and collection}

The result of the study shows the titles and volumes of the library holdings and collections within the last five years. General Reference had Encyclopedias $(17,53)$ and other general reference books such as atlases, almanacks, dictionaries, handbooks, manuals, etc. $(164,584)$. General Collection Books has Generalities $(236,424)$, Philosophy $(79$, 176), Religion (11, 13), Social Science (506, 915), Pure Science (116, 292), Applied Sciences $(605,800)$, Arts (64, 75), Literature $(179,573)$, History $(63,127)$, Fictions $(123,125)$. The total number of books was 2,447 titles and 4,770 volumes, and the Filipiniana Collection had 482 titles and 1,495 volumes. Periodicals have Magazines/Journals (225), and Newspaper, both broadsheet and tabloids (5), have a total of 230 titles. The NVSU Academic Library had 2,929 titles with 6,265 volumes of books copyrighted within the last ten years, and 10\% of these or 293 titles were published within the last five years. Filipiniana had a 7\% collection from the total base collection. Based on the Philippine Association of Academic and Research Libraries (PAARL) standard, the NVSU Academic Library achieved the minimum standard for titles of books, but it failed to achieve the standard for Filipiniana and the core collection published within the last five years. For periodicals and serials, the minimum requirement for titles of periodicals was met, but the collection lacked the required number of titles per curricular program. As supported by Conti (2010) \& Kim (2017), collection development needs careful planning to acquire important support to its mission in serving the needs of the academic society. The annual growth rate of collection shall be maintained for every program offering and enrolment (Oakleaf, 2017).

\section{On Resources on non-print materials and ICT equipment}

The result shows that maps had 12 units, globe (1), Posters (3, transparencies (4), instructional tapes (174), cassette tapes (30), CD-ROMS (47), and slide film (50) non-print materials have a total of 358 functional units. Additionally, the total units and the number of functional/usable units under audiovisual equipment shows the audiovisual equipment had television (2), desktop computer (10), laptop (3), LCD projector (2), printer (4), photocopying machine (2), Scanner (1). PAARL states that non-print materials and electronic/digital resources, availability of CD-ROMs, e-resources, and online databases shall be made available through adequate facilities. Special collections and relevant multimedia and electronic resources, in agreement with the Intellectual Property Code, should be included to meet the requirements of the various programs and courses offered by an institution (Doherty, 2014). Particular consideration shall be given to the availability of internet services and information and technology communications to supplement the library's collection and information resources (Besiki \& Gibradze, 2017; Akintola \& Olayiwola, 2004). Libraries of today must meet the various needs of the society as library users prefer more computer indices, digitized findings aids, and digital repositories of articles (Sun \& Yuan, 2012; Gako \& Laspinas, 2015).

\section{On Library Facilities}

The total and number of functional/usable facilities of NVSU Academic Library included a reading area of (990 sq. m), movable shelves (64), charging desk (15); magazine racks (5), chairs (584), reading tables (92), and individual study carrels (15). On providing essential external, the library has ventilation (80), the lighting system (192), toilet facilities (8), wooden card catalogues (4), index to periodicals (5), OPAC (1), vertical files (5), bulletin boards (10), bamboo sala set (3); working tables (14). On other critical physical fixtures and appliances, there were fire extinguishers (7), typewriters (2), telephone unit (1), Air conditioning units (3); barcode readers (3).

PAARL Standard (2010) states that the library shall be accessible at any point of activity on the campus. It should meet the housing requirements of its collections, including space for automated services. The reading area of the library with two square meters per user should accommodate $20 \%$ of the total enrollment population at once. There should also be provided for future expansion. The NVSU Academic Library is strategically located within the campus and is accessible 
to the academic community. The library provides different facilities such as standard furniture and equipment that facilitate the services and promote operational efficiency and effectiveness of use. It also provides safety and comfort to library users. However, the library failed to meet the standard $20 \%$ space requirement. The insufficiency of space is due to the fast-growing population of state universities as private higher education institutions continually increase fees.

\section{On Library Personnel}

The NVSU library personnel included licensed and competent librarians (6); student assistants (5), Administrative aide (1), utility personnel (1), bookbinder (1), with a total of 14 personnel. The support staff is provided to meet academic needs. The Philippine Republic Act 9246 governs the practice of Librarianship and professionalization of the profession. The Accrediting Agency of Chartered Colleges and Universities of the Philippines (AACCUP) Manual of Accreditation requires that the library be managed by a full-time staff. He or she should hold a Master's degree in Library Science or Information Science and should be classified as academic non-teaching staff.

\section{The Extent of Functional Effectiveness of Library Services in terms of holding}

Table 1 shows the extent of the functional effectiveness of library services on holdings. The respondents rated the collection of library services as functioning and very effective with a weighted mean rating of 2.6886. The respondents perceived that library core collections were adequate and the current edition to support students' curricular needs. The maintenance of an extensive Filipiniana collection and subscription to professional journals, magazines, and other serials support curricular programs. The library has a well-organized library collection, classified according to a classification scheme and easy to find. Moreover, the availability of non-print collections like slides, CDs, filmstrips, etc. were functional and effective. With hardware relevant to students' needs was described as functioning and effective. The extent of satisfaction of library users marks the effectiveness and efficiency of academic services. More than adequacy, the wise utilization of the library resources makes for efficiency in the library area (Soria, Fransen \& Nackerud, 2017).

Table 1: The Extent of Functional Effectiveness of Library Services on Holdings

\begin{tabular}{lll}
\hline Holdings & Mean & Qualitative Description \\
\hline $\begin{array}{l}\text { 1. The library core collections are adequate and of the } \\
\text { current edition to support my curricular needs. }\end{array}$ & Functioning and Very Effective \\
\hline 2. The library maintains an extensive Filipiniana collection & 2.9272 & Functioning and Very Effective \\
\hline $\begin{array}{l}\text { 3. The library subscribes to professional journals, } \\
\text { magazines, and other serials that support curricular } \\
\text { programs. }\end{array}$ & & Functioning and Very Effective \\
\hline $\begin{array}{l}\text { The library collection is well-organized, classified } \\
\text { according to a classification scheme, and easy to find }\end{array}$ & Functioning and Very Effective \\
\hline $\begin{array}{l}\text { The library has a non-print electronic collection (slide, } \\
\text { needs. }\end{array}$ & Functioning and Effective \\
\hline Mean & 2.9623 & \\
\hline
\end{tabular}

\section{Physical Facilities}

Table 2 displays the perception level of the respondents on the functional effectiveness of library services in terms of physical facilities. The respondents perceived the physical facilities of the library as functioning and effective with a mean of 2.1291. In addition, the respondents perceived the following to be functioning and very effective: 1) maintaining a conducive environment (minimal noise level, adequate lights for studying); 2) providing adequate access to electronic and online references; 3 ) gaining accessibility to visitors and library users. On the other hand, students perceived the following to be functioning poorly and not effective: 1) computers and internet facility for searching online reference sources; and 2) the availability of photocopying machines. The technology innovation management must find support to the evolution from traditional libraries to electronic and digital libraries $\underline{\text { Reddy (2017). }}$.

Table 2: The Extent of Functional Effectiveness of Library Services on Physical Facilities

\begin{tabular}{lll}
\hline Physical facilities & Mean & Qualitative Description \\
\hline $\begin{array}{l}\text { 1. The library environment is conducive to studying (noise } \\
\text { level, heating/cooling, lights, furniture, and cleanliness). }\end{array}$ & & Functional and Very Effective \\
\hline $\begin{array}{l}\text { 2. The library is convenient and accessible to visitors and } \\
\text { library users. }\end{array}$ & Functional and Very Effective \\
\hline $\begin{array}{l}\text { 3. Library provides access to adequate electronic reference } \\
\text { sources and online resources for research and } \\
\text { information. }\end{array}$ & & Functional and Very Effective \\
$\begin{array}{l}\text { 4. Library provides adequate computers and a good internet } \\
\text { facility for searching online reference sources. }\end{array}$ & & $\begin{array}{l}\text { Functioning Poorly and } \\
\text { not Effective }\end{array}$ \\
\hline
\end{tabular}




\begin{tabular}{lll}
\hline 5. The library provides a photocopy machine & 1.2407 & $\begin{array}{l}\text { Functioning Poorly and } \\
\text { not Effective }\end{array}$ \\
\hline Mean & 2.1291 & Functioning and Effective \\
\hline
\end{tabular}

\section{Library Services}

Table 3 reveals the perception of the respondents on the functional effectiveness of library services having a weighted mean score of 2.6582. The result implies that respondents perceived the library services as functioning and very effective. The result further showed that the respondents saw the library services as functioning and very effective: 1) The opening/closing hours of the library meet the students' needs; 2) library system which provides faculty, students and other users greater access to its collection and services; and 3) having informative, helpful, and easy-to-use web pages and useful sources for e-reference services. The following were functioning and effective: 4) Current Awareness Services (CAS) in bulletin boards and hard copies keep the students aware of available resources and 5) access to adequate electronic reference sources for research and information. Generally, this indicates that the services of the library are perceived to be functioning and very effective. Hernon \&Altman (2010) \& Kiran (2010) underscored that only customers judge quality, hence, should meet needs and expectation since the library is a primary place for learning. Along with the provision of information services, equipment, and facilities, effective library management complements (Kim 2017). Nikonova (2020) emphasized the need for modernization of the modern system of higher technical education.

Table 3: The Extent of Functional Effectiveness of Library Services

\begin{tabular}{lll}
\hline Services & Mean & Qualitative Description \\
\hline $\begin{array}{l}\text { 1. Opening/ closing hours (7:30-11:30, 1:00-5:00) of the } \\
\text { library meets my needs. }\end{array}$ & Functioning and Very Effective \\
\hline $\begin{array}{l}\text { 2. The library adopts a system (open shelf) that provides } \\
\text { the faculty, students, and other users greater access to its } \\
\text { collection and services. }\end{array}$ & Functioning and Very Effective \\
\hline $\begin{array}{l}\text { 3. Current Awareness Services (CAS) on the bulletin board } \\
\text { and hard copies keep me aware of available resources. }\end{array}$ & \\
\hline $\begin{array}{l}\text { 4. Library web pages are available, informative, helpful, } \\
\text { and easy to use and a good source for e-reference } \\
\text { services. }\end{array}$ & Functioning and Effective \\
\hline $\begin{array}{l}\text { 5. Library provides access to adequate electronic reference } \\
\text { sources for research and information. }\end{array}$ & Functioning and Very Effective \\
\hline Mean & 2.600 & Functioning and Effective \\
\hline
\end{tabular}

\section{Library Personnel}

In table 4, the respondents perceived the level of functional effectiveness of library personnel as functioning and very effective with a weighted mean of 2.8464 . The students observed that the library personnel were competent and helpful as they demonstrated excellent communication skills and human relation skills. They immediately answered questions, and they demonstrated technical library skills. They considered the number of library staff and personnel as competent in delivering library services. It implies that the library personnel were functioning and very useful. Qualified personnel, adequate holdings, and facilities were not enough. Library Personnel and sufficient holdings and facilities balance effective services (Young \& Kelly, 2019).

Table 4: The Extent of Functional Effectiveness of Library Personnel

\begin{tabular}{lcc}
\hline Library Personnel & Mean & Qualitative Description \\
\hline $\begin{array}{l}\text { 1. Library personnel are competent and helpful. } \\
\text { 2. Library staff demonstrates excellent communication and } \\
\text { human relations skill }\end{array}$ & 2.9821 & Functioning and Very Effective \\
\hline $\begin{array}{l}\text { 3. Library staff immediately answers ready reference } \\
\text { questions }\end{array}$ & 2.9107 & Functioning and Very Effective \\
\hline $\begin{array}{l}\text { 4. The number of staff and personnel is enough to deliver } \\
\text { library services }\end{array}$ & 2.8036 & Functioning and Very Effective \\
\hline 5. The library staff demonstrates technical library skills & 2.6964 & Functioning and Very Effective \\
\hline Mean & 2.8464 & Functioning and Very Effective \\
\hline
\end{tabular}

Overall Extent of Functional Effectiveness of Library Services

Table 5: The Overall Extent of the Functional Effectiveness of Library Services

\begin{tabular}{lll}
\hline Library Personnel & Mean & Qualitative Description \\
\hline 1. Holdings & 2.6886 & Functioning and Very Effective \\
\hline 2. Physical Facilities & 2.1291 & Functioning and Very Effective \\
\hline
\end{tabular}




\begin{tabular}{lll}
\hline 3. Services & 2.6582 & Functioning and Very Effective \\
\hline 4. Library Personnel & 2.8464 & Functioning and Very Effective \\
\hline Mean & 2.5806 & Functioning and Very Effective \\
\hline
\end{tabular}

As a summary, the respondents perceived the functional effectiveness of library services in all areas as functioning and very effective with an overall weighted mean of 2.5806. According to the PAARL standards, the maximum standard that a library service can attain is functioning and excellently effective. But the result of this study shows library services were functioning and very effective. The NVSU library services met the standard but have yet to reach the maximum required. The efforts to achieve optimal standards, optimum use must be a goal of the study school.

\section{CONCLUSION}

The collection of the NVSU academic library surpassed the minimum standard of the required number of titles of books. Still, they failed to achieve the set standards for Filipiniana collection and the core collection published within the last five years. For periodicals and serials, the minimum requirement for titles was satisfied but failed to meet the required number of titles in some curricular programs. Although non-print and electronic resources were available, they need to be upgraded. The library offers appropriate facilities that were accessible to library users. They met the minimum requirements, but the library shall comply with the $20 \%$ adequacy standard for space.

Likewise, students also perceived that computers and internet facilities for searching online reference sources and photocopying machines were functioning poorly and not effective. The number of full time-qualified and licensed librarians and support staff to organize and manage services for clientele was sufficient. The library services of NVSU were functioning and very effective. However, the University library continually needed improvement to provide excellent library services based on Library Standards.

Based on the conclusions, future researchers may review for possible consideration: The library may consider establishing a resource sharing scheme with academic libraries through a consortium. Management needs to consider upgrading the information and technology infrastructure in the library so students may access more learning resources. The limitless availability of information obtained from the net may partially solve the insufficient books and periodicals. Relocate offices and other function rooms to give way to the growing students and faculty population.

To achieve the goals set in the Library Improvement Plan, collaboration among the administration and library council and staff must be a continuing endeavour. Management training and skills development for librarians and other library staff must keep up with the development of the library. Library staff has to be adept with development. Blended learning, teleconferencing, teaching aid, and technology production and use, presentation, and other communication skills must be their strength.

\section{LIMITATION AND STUDY FORWARD}

The limitation of the study included the non-involvement of the experiences and evaluation of other library users from faculty members, researchers, and library council to measure and attest the functional effectiveness of the library services, thus, limited only to the Nueva Vizcaya State University, Philippines. The paper could still consider the conditions of other libraries. A sequel research study may consider a broader scope with a more significant number of respondents and consider other variables to continually build responsive library services.

\section{REFERENCES}

1. Abdallah, F. \& Bilal, D. (2015). Exploring the Effectiveness of Library Services and Resources in Academic Libraries in Lebanon from Users' Perspective. IFLA WLIC. http//creative commons.org/licenses/by/3.0/

2. Agosto,D.E., Paone, K.L., \& Ipock, G.S. (2007). The Female Friendly Public Library: Gender differences in adolescents' uses and perceptions of US public library. Library Trends, Vol 56, No. 2, 387-401. https://doi.org/10.1353/lib.2008.0000

3. Al Hjjii, K.Z. \& Coz, A.M. (2012). Performance measurement methods at academic libraries in Oman. Performance Measurement and Metrics, 13(3), 183-196. https://doi.org/10.1108/14678041211284722

4. Aina, L.O. (2004). Coping with the Challenges of Library and Information Services Delivery: The Need for Institutionalized Professional Development. Being a Paper Delivered at 2004 NLA National Conference and AGM held in Akure on June 20-25, p.4. Library and Information Science text for Africa, Nigeria: Third Information Service Ltd.

5. Akintola, B.A., \& I.B. Olayiwola (2004). Academic libraries: The Internet and Its Potential Impact on Teaching and learning in Nigerian tertiary institutions. Journal of Library and Information Science 1 (1\&2): 34-46.

6. Bamidele IA, SU Omeluzor, E. Madukoma, PN George, and S.Ogbuiyi (2012). Comparative Study of Faculty Members' Expectations of Academic Library Services in Three Universities in Ogun State, Nigeria. Canadian Social Science Vol. 8, No. 4, 2012, pp. 202-210 DOI:10.3968/j.css.1923669720120804.1855.

7. Bassey, B.A. (2006). User-satisfaction with services in three academic libraries in Cross River State: a comparative study. Gateway Library Journal. 21-29. 
8. Besiki, S. \& Gibradze, L. ( 2017). Examining Undergraduate Students' Priorities for Academic Library Services and Social Media Communication. The Journal of Academic Librarianship. http://dx.doi/10.1016/j.acalib. 2017.02.013.

9. Brophy, P. (2006). Quality Management for Information and Library Managers. USA:aSLIB GOWER.

10. Conti, E.L. (2010). Standards for Philippine School Libraries. Available online. http//paarl.wikispace.com/

11. Dahan, Suziyana M., M. Y. Taib, N. M. Zainudin, F. Ismail. (2016). Surveying Users' Perception of Academic Library Services Quality: A Case study in Universiti Malaysia Pahang (UMP) Library. Journal of Academic Librarianship, vol.42(1) January 2016 pp38-43. https://doi.org/10.1016/j.acalib.2015.10.006

12. Doherty, T. (2014). Why do Still Need Public Libraries in the Digital Age? British Council.org (retrieved on March 26, 2016, https://www.britishcouncil.org/voices-magazine/why-still-need-public-libraries-digital-age.

13. Echezona, R.I., \& Edoka, B.E. (2009). Information Services Provision by Special Collection Units in Federal and State Nigerian University Libraries. An International Journal of Information and Communication Technology, 6(1).

14. Fassoulis, M. \& Fassoulis, K. (2017). Knowledge Management Perceptions in Academic Libraries. The Journal of Academic Librarianship. Volume 43(2). Pages 135-142. https://doi.org/10.1016/ j.acalib.2016.11.006.

15. Freeman, G.T. (2005).The library as place: changes in learning patterns, collection, technology, and use. Library as place: rethinking roles space. Council on Library and Information Resources, Washington .DC., 1-9.

16. Francisco, J. P. (2008). Users' Evaluation of the Library of the F.L. Vargas College Tuguegarao City Based on the PACU-COA Standards: Towards A Proposed Lib. Development Plan. Unpublished Master's Thesis. Saint Mary's University, Philippines. Available online at http://lisresearchphil.blogspot.com/2008/11/ users evaluation-of-library-of-f.html

17. Gako, L. D. \& Laspinas, M.L. (2015). The functionality of an Academic Library Using Standard for Philippine Academic Libraries Model. Cebu Technological University; Cebu Normal University, Cebu City, Philippines. Asia Pacific Journal of Education, Arts, and Sciences, Vol. 2 No. 2, April 2015 pp68-75.

18. Gibson, A., Chancellor, R., Cooke, N., Dahlen, S., Lee, S.A. \& Shorish, Y. (2017). Libraries on the Frontlines: Neutrality and Social Justice, Equality, Diversity and Inclusion. An International Journal, Vol 36 No. 8. 751 766. https://doi.org/10.1108/EDI-11-2016-0100

19. Gulati, A. (2010). Diversity in Librarianship: the United States Perspective, IFLA Journal, vol. 36 no. 4, 288 293. https://doi.org/10.1177/0340035210388244

20. Haruna, I. \& Oyelekan, G.O. (2010). Provision and Utilization of Information Resources and Services in the Nigerian Defense Academy (NDA) Library, Kaduna. Information Technologist, 7(1). https://doi.org/10.4314/ict.v7i1.60426

21. Jaeger, P.T. \& Franklin, R.E. (2017). The Virtuous Circle: Increasing Diversity LIS faculties to create more inclusive library services outreach. Education Libraries. Vol 30, n. 1, 20-26. https://doi.org/10.26443/el.v30i1.233

22. Jantz, R.C. (2012). Innovation in Academic Libraries: An analysis of of University Librarians' Perspective. Library and Information Science Research, vol 34 N0. 1, 3-12. https://doi.org/10.1016/j.lisr.2011.07.008

23. Kanduik, m. (2014). Promoting Racial and Ethnic diversity among Canadian Academic librarians. College and and Research Libraries, vol. 75. No. 4, 292-556. https://doi.org/10.5860/crl.75.4.492

24. Kim, J.A. (2017). User Perception and Use of the Academic Library: A correlation Analysis. The Journal of Academic Librarianship. https://doi.org/10.1016/j.acalib.2017.03.002

25. King, F., Buss, W.C., Cohen, N., Stanley, D. \& White, E. (2008). The University of Georgia students learning centre. In P. Hermon\& RR Powel (eds). Convergence and collaboration of campus information services (pp 125-139) Westport, CT: Libraries unlimited.

26. Sun, J. \& Yuan, B. (2012). Development and Characteristics of Digital Library as a Library Branch. IERI Procedia. 2(2012) 12-17. https://doi.org/10.1016/j.ieri.2012.06.044

27. Hapha, Y, \& Somprach, K. (2019) A Study of Digital Leadership and Creative Leadership that affect Innovation in Thai Higher Education. Journal of Critical Reviews, 6 (4), 37-41.

28. Hernon, P., \& Altman, E. (2010). Assessing service quality: satisfying the expectations of library customers. 2nd ed. Chicago: American Library Association.

29. Hernon, P. \& McClure, C. (1990). Evaluating and Library Decision Making. Norwood, New Jersey: Ables Publishing.

30. Kadiri J.A. (2000) Academic Status for Librarians in Ghanaian Universities: Challenges to Stakeholders. Gateway Library Journal (2\&3):97-103.

31. Kim, J.A. (2017). User Perception and use of the Academic Library: A Correlation Analysis. The Journal of Academic Librarianship. https://doi.org/10.1016/j.acalib.2017.03.002

32. Kiran, K. (2010). Service quality and customer satisfaction in academic libraries: a perspective from a Malaysian University. Library Review, 59(4), 2261-273. https://doi.org/10.1108/00242531011038578

33. Lawson, K. (2004). Libraries in the USA as traditional and virtual "third place". New Library World, 105(1198)/11990 125-130. https://doi.org/10.1108/03074800410526758 
34. Manafu, S. (2016). The Design and Implementation of Knowledge Management Systems in Academic Libraries to enable Knowledge Management Processes: a case study of Makerere University Library. URI: http://hdl.handle.net/2263/62110

35. Murray, Adam, Ashley Ireland, and Jana Hackathorn. (2016). The Value of Academic Libraries: Library Services as Predictor of Student Retention. College and Research Libraries (C\&RL) September 2016 pp.631642. https://doi.org/10.5860/crl.77.5.631

36. Nikonova, N. P. (2020). Modern Requirements for Quality of Higher Technical Education in Russia. Journal of Critical Review, vol 7(1).

37. Mustafa, F. \& Noorhidawati, A. (2015). Adoption and Implementation of evidence-based library acquisition of electronic resources. Malaysian Journal of Library Science, vol 25(1), 1-29.

38. Matthews, J.R. (2014). Library Assessment in Higher Education. (2 ${ }^{\text {nd }}$ ed) Santa Barbara, CA: Libraries Unlimited.

39. Oakleaf, M. (2010). Value of Academic Libraries: A Comprehensive Research Review and Report. Chicago:, Il: American Library Association.

40. Oakleaf, M, and KyrillidouM. (2016). Revisiting the Academic Library Value Research Agenda: an opportunity. The Journal of Academic Librarianship vol 42 pp757-764. https://doi.org/10.1016/j.acalib.2016.10.005

41. Obille, K. L. (2007). An Evaluation of Standards for Academic Libraries in the Philippines. Journal of Philippine Librarianship, 27 (1\&2): pp. 109-150. Available online at http://journals.up.

42. PAARL: Philippine Association of Academic and Research Libraries Standards (PAARL) for Academic Libraries for 2010. Available online at http//www.dlsu.edu.ph/paarl/activities/projects.asp

43. Reddy, J. K. (2017). Knowledge Management in 21st Century Academic Libraries. International Journal of Library and Information Studies Vol.7(2) Apr-Jun, 2017 ISSN: 2231-4911 pp115-120.

44. Roberts, S.T. \& Nobel, S.U. (2016). Empowered to name, inspired to act: Social Responsibility and Diversity as calls to action in the LIS context. Library Trends. Vol. 59 no. 1, 109-127. https://doi.org/10.1353/lib.2016.0008

45. Soria, K.M., Fransen, J., \& Nackerud, N. (2017). Academic Benefits of Library Use for First-Year College Students. College \& Research Libraries, Vol 78, No 1. https://doi.org/10.5860/crl.78.1.8

46. Taylor, R.S. (1986). Value Added Processes in Information System. Norwood, New Jersey: Ablex Publishing.

47. The Accrediting Agency of Chartered Colleges and Universities of the Philippines (AACCUP) Manual of Accreditation 2015.

48. Umunnakwe, G. C. \& C O Onyebinama. (2007). Academic library services in Imo State: the challenges so far. The Information Technologist Vol. 4 (2) 2007: pp. 163-174. https://doi.org/10.4314/ict.v4i2.31995

49. Whitehall, T. (1992). Quality in Information Service: A review. Library Management, 13(5), 23-35. https://doi.org/10.1108/01435129210020361

50. Young, BW, and Kelly, L. (2018). How well do we know our students? A comparison of students' priorities for Services and librarians' Perceptions of Those Priorities. The Journal of Academic Librarianship. Volume 44(2), March 2018, Pages 173-178. https://doi.org/10.1016/j.acalib.2018.02.010 